\title{
PERSPESI PENGGUNA TERHADAP KENYAMANAN TERMAL DI AREA THRESHOLD PADA IKLIM MIKRO
}

\author{
Panji Anom Ramawangsa, ${ }^{,}$Atik Prihatiningrum ${ }^{2}$ \\ ${ }^{1,2}$ Program Studi Arsitektur, Fakultas Teknik, Universitas Bengkulu. \\ JI. W.R Supratman, Kandang Limun, Kec. Muara Bangkahulu, Bengkulu, 38371 \\ 'panji.anomr@unib.ac.id
}

Diterima: 31-10-2020 Direview : 22-11-2020 Direvisi : 11-01-2021 Disetujui: 11-01-2021

ABSTRAK. Dalam merancang bangunan perlu mempertimbangkan kondisi iklim di sekitarnya. Threshold space merupakan area transisi antar ruang luar dan dalam yang mengandung pengalaman ruang yang sesuai dengan persepsi dan psikologis pengguna. Iklim mikro merupakan kondisi iklim yang ada di suatu wilayah yang sangat terbatas kurang lebih 2 (dua) meter setinggi permukaan tanah. Penelitian ini berfokus pada kenyamanan ruang bagi pengguna ruang threshold di area teras gedung dekanat Universitas Bengkulu. Metode penelitian ini menggunakan metode kuantitatif yang diawali dengan tahap pengamatan, pengumpulan data, dan penyebaran kuesioner. Berdasarkan analisis yang telah dilakukan, hasil responden terhadap kenyamanan ruang threshold gedung dekanat kemudian dikomparasi dengan hasil nilai Temperatur Humidity Index (THI) dan perhitungan Rayman.

Kata kunci: kenyamanan, THI, threshold, Rayman

ABSTRACT. In designing a building, it is necessary to consider the surrounding climatic conditions. Threshold space is a transitional area between outer and inner spaces that contains spatial experiences by following the user's perceptions and psychology. A microclimate is a climatic condition in a very limited area of approximately 2 (two) meters as high as the ground surface. This study focuses on the comfort of space for users of the threshold space in the terrace area of the Dean building, Bengkulu University. This research method uses quantitative methods that begin with the observation, data collection, and distribution of questionnaires. Based on the analysis that has been done, the respondent's results on the comfort of the threshold room of the dean building are then compared with the results of the Temperature Humidity Index (THI) value and Rayman's calculation.

Keywords: convenience, THI, threshold, Rayman

\section{PENDAHULUAN}

Dalam merancang bangunan perlu mempertimbangkan kondisi iklim di sekitarnya, dalam hal ini wujud bangunan memegang peranan penting dalam mengontrol dan mereduksi kondisi iklim setempat. Untuk mencapai bentuk fasad bangunan yang optimal, maka perlu melakukan pemahaman terhadap perilaku iklim dalam menghasilkan wujud fasad yang tanggap terhadap kondisi iklim setempat, tanpa terkecuali iklim mikro.

Threshold space merupakan area transisi antar ruang luar dan dalam yang mengandung pengalaman ruang yang sesuai dengan persepsi dan psikologis pengguna (Nio \& Dewi, 2017). Dalam kasus ruang publik, threshold berperan penting sebagai pengikat dan mempertegas hubungan ruang yang ada disuatu area (Dikwatama et al., 2019). Gedung dekanat di Universitas Bengkulu memiliki ruang transisi yang berperan sebagai threshold dalam memenuhi aktifitas penghuni di dalam bangunan. Teras merupakan salah satu elemen pada bangunan yang berfungsi sebagai area transisi antara ruang luar dan ruang dalam bangunan. Berdasarkan data observasi dilapangan, area ini difungsikan sebagai ruang tunggu bagi mahasiswa, dan ruang bersosial.

Iklim mikro merupakan kondisi iklim yang ada di suatu wilayah yang sangat terbatas kurang lebih 2 (dua) meter setinggi permukaan tanah (Santi et al., 2019). Nilai rata-rata suhu dan kelembaban yang ada dikawasan, dipengaruhi oleh tutupan lahan yang ada di area tersebut (Sanger et al., 2016).

Indikator kenyamanan termal bagi para penghuni dapat diketahui melalui beberapa cara, yaitu dengan menggunakan Temperatur Humidity Index (THI), dan analisis Rayman. Temperatur Humidity Index (THI) merupakan formula untuk mengukur tingkat 
kenyamanan yang ada di suatu tempat yang dipengaruhi oleh kelembaban dan temperatur udara (Santi et al., 2019). Analisis Rayman adalah teknik mengolah data responden yang ada di objek penelitian dengan memasukkan beberapa variable data untuk mendapatkan nilai PMV, PET, SET, dan SVF (Matzarakis \& Rutz, 2006).

Menurut (Talarosha, 2005), terdapat 3 (tiga) komponen iklim yang menjadi parameter penentu kenyamanan ruang yaitu :

\section{Temperatur udara}

Kriteria kenyamanan suhu udara bagi penduduk Indonesia terbagi atas 3 (tiga) yaitu,
a. sejuk nyaman dengan suhu $20,5{ }^{\circ} \mathrm{C}-$ $22,8^{\circ} \mathrm{C}$
b. nyaman optimal dengan suhu $22,8^{\circ} \mathrm{C}$ $-25,8^{\circ} \mathrm{C}$
c. hangat nyaman dengan suhu $25,8^{\circ} \mathrm{C}$ $-27,1^{\circ} \mathrm{C}$

2. Kelembaban udara

Kelembaban udara dengan kadar air di udara yang baik untuk tubuh berkisar antara $40 \%-70 \%$. Pada wilayah tertentu seperti tepi pantai kelembaban berkisar $80 \%-98 \%$.

3. Angin

Kenyamanan angin untuk kenyamanan dalam ruangan berada pada batas kecepatan antara 0,1 m/detik sampai 0,5 $\mathrm{m} /$ detik dan apabila kecepatan angin berada diatas nilai ini dapat dikatakan tidak nyaman.

Standar kenyamanan di lingkungan kerja yaitu nilai temperature ruang berkisar $18^{\circ} \mathrm{C}-26^{\circ} \mathrm{C}$, temperature ruang luar bekisar $20.5^{\circ} \mathrm{C}-31$ ${ }^{\circ} \mathrm{C}$ dan batas kenyamanan kelembaban berkisar $40 \%-60 \%$. Batas nyaman kecepatan angin ruang dalam berkisar $0.15 \mathrm{~m} / \mathrm{s}$ sampai $0.25 \mathrm{~m} / \mathrm{s}$ (MENKES:NO.261/ MENKES /SK/II/ 1998,1998). Berdasarkan SNI 03-2396-2001, batas kenyamanan iluminasi suatu ruang lobby dan koridor berkisar 100 lux (Badan Standardisasi Nasional, 2001).

Universitas Bengkulu merupakan kawasan pendidikan yang memiliki karakteristik lingkungan yang sangat asri dengan di kelilingi ruang hijau yang menjadi habitat beberapa fauna yang ada. Kondisi kampus yang berkomitmen dengan penghijauan di area kampus serta keberlanjutan lingkungan ini dipertegas dengan eksistensi Universitas Bengkulu berada di peringkat ke -23 dari 72 perguruan tinggi se Indonesia pada tahun 2019 yang dilakukan oleh UI Greenmetric (GreenMetric, 2019). Salah satu indikator penilaian dalan pemeringkatan ini adalah kondisi iklim setempat, area hijau, dan ruang terbuka yang memegang peranan penting dalam mengatur kondisi iklim mikro yang ada di kawasan kampus.

Penelitian terdahulu yang membahas tentang kondisi kenyamanan termal di lingkungan kampus dengan metode perhitungan Rayman telah pernah dilakukan oleh (Sumaryata et al., 2019) untuk mengetahui persepsi dan preferensi kenyamanan termal di area koridor di kawasan kampus Institut Teknologi Bandung (ITB) dan perhitungan THI pada kawasan ruang luar juga telah dilakukan oleh (Santi et al., 2019), namun untuk kondisi kenyamanan termal pada area threshold pada kawasan kampus dalam 5 (lima) tahun terakhir belum pernah dilakukan.

Penelitian ini berfokus pada kenyamanan ruang bagi pengguna ruang threshold di area teras gedung dekanat Universitas Bengkulu ditinjau dari hasil koesioner, nilai THI, dan perhitungan Rayman.

\section{METODE PENELITIAN}

\section{Lokasi dan Waktu Penelitian}

Penelitian dilakukan di Gedung Dekanat Fakultas Ekonomi dan Bisnis (FEB) dan Fakultas Hukum (FH) Universitas Bengkulu. Gedung dekanat FEB dibangun pada tahun 1987 dan gedung $\mathrm{FH}$ dibangun pada tahun 2017. Kedua bangunan memiliki ciri khas arsitektur yang sangat berbeda.

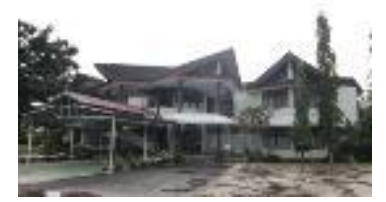

a

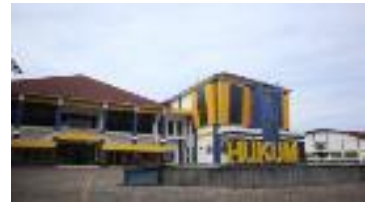

b
Gambar 1 (a) Gedung Dekanat Fakultas

Ekonomi dan Bisnis, (b) Gedung Dekanat Fakultas Hukum

Secara astronomis gedung FEB berada di titik koordinat $3^{\circ} 45^{\prime} 43.1^{\prime \prime S} 102^{\circ} 16^{\prime} 08.3^{\prime \prime} E$ dengan arah orientasi menghadap barat dan gedung dekanat $\mathrm{FH}$ di titik koordinat $3^{\circ} 45^{\prime} 38.2^{\prime \prime S}$ $102^{\circ} 16^{\prime} 06.1$ "E menghadap barat laut. 


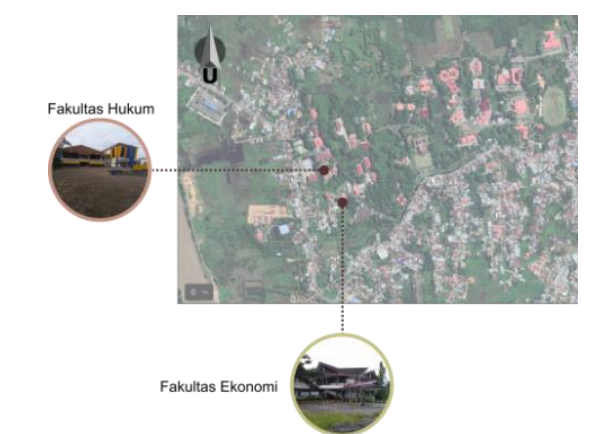

Gambar 2. Letak lokasi penelitian di Universitas Bengkulu

Sumber : Gambar diolah dari Google Earth

\section{Tahapan Penelitian}

Metode penelitian ini merupakan metode kuantitatif yang diawali dengan tahap pengamatan dan pengumpulan data suhu udara dan kelembaban secara langsung di area threshold gedung dekanat FEB dan $\mathrm{FH}$. Pengambilan data dilakukan sebanyak 3 (tiga) kali dalam satu hari yaitu pukul 07.00, 12.00, dan 17.00, selama 1 (satu) minggu pada bulan Agustus 2020. Pengambilan data menggunakan alat thermometer, hygrometer, dan anemometer.

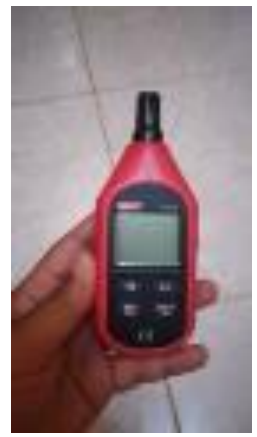

a

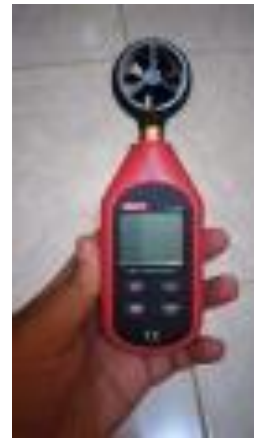

b
Gambar 3. Alat pengumpulan data, (a) thermometer dan hygrometer, dan (b) anemometer

Hasil data pengukuran kemudian di analisis dengan menggunakan indeks kenyamanan THI. Metode ini menggunakan data suhu dan kelembaban yang diperoleh di lokasi penelitian kemudian dihitung dengan rumus ;

Keterangan:

$$
\mathrm{THI}=0.8+(\mathrm{RH} X \mathrm{~T}) / 500
$$

THI : Temperature Humidity Index

$\mathrm{T}$ : Suhu udara $\left({ }^{\circ} \mathrm{C}\right)$

$\mathrm{RH} \quad$ : Kelembaban relative (\%)

Metode ini menggunakan selang kenyamanan berdasarkan Nieuwolt (Nieuwolt, 1977) yang kemudian di modifikasi Effendy (Effendy, 2007). Untuk iklim tropis dengan nilai suhu nyaman $\mathrm{THI}$ antara $25-29^{\circ} \mathrm{C}$ dan kelembaban $40-75 \%$.

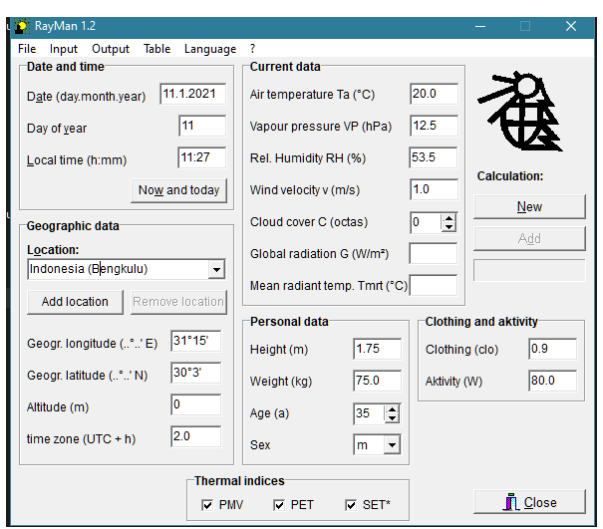

Gambar 4 Software Rayman

Untuk mendapatkan nilai PET (Physiological Equivalent Temperature), diperlukan beberapa responden sebagai pelaku di lapangan. Data responden meliputi usia, jenis kelamin, jenis pakaian, dan aktifitas. Data ini dilengkapi dengan data primer iklim mikro yang ada di kawasan gedung dekanat (Paramita \& Matzarakis, 2019). Hasil nilai olah data Rayman, kemudian dikonversikan kedalam indeks skala PET untuk menentukan beban psikologis bagi responden dalam merasakan kondisi suhu fisiologis yang ada di kawasan tertentu berdasarkan suhu ruang, aktifitas, dan jenis pakaian yang dikenakan (Sumaryata et al., 2019) (Höppe, 1999).

Tabel 1 Skala PET dan tingkat stress fisiologis

\begin{tabular}{|c|c|c|c|}
\hline PMV & PET & $\begin{array}{l}\text { Sensasi } \\
\text { Termal }\end{array}$ & $\begin{array}{l}\text { Tingkat stres } \\
\text { fisiologis }\end{array}$ \\
\hline-3.5 & 4 & $\begin{array}{l}\text { Sangat } \\
\text { dingin }\end{array}$ & $\begin{array}{c}\text { Stres dingin yang } \\
\text { ekstrim }\end{array}$ \\
\hline-2.5 & 8 & Dingin & $\begin{array}{c}\text { Stres dingin yang } \\
\text { kuat }\end{array}$ \\
\hline-1.5 & 13 & Dingin & Stres dingin sedang \\
\hline-0.5 & 18 & $\begin{array}{l}\text { Sedikit } \\
\text { dingin }\end{array}$ & Stres dingin ringan \\
\hline 0.5 & 23 & Nyaman & $\begin{array}{c}\text { Tidak ada stres } \\
\text { termal }\end{array}$ \\
\hline 1.5 & 29 & $\begin{array}{l}\text { Sedikit } \\
\text { hangat }\end{array}$ & Stres panas sedang \\
\hline 2.5 & 35 & Hangat & $\begin{array}{c}\text { Stres panas yang } \\
\text { kuat }\end{array}$ \\
\hline 3.5 & 41 & Panas & $\begin{array}{c}\text { Stres panas yang } \\
\text { ekstrim }\end{array}$ \\
\hline
\end{tabular}

Sumber : (Sumaryata et al., 2019) (Höppe, 1999)

Kemudian metode penelitian dilanjutkan dengan penyebaran kuesioner secara online ke setiap penguna ruang threshold di gedung FEB dan FH. Metode ini bersifat kuantitatif eksplanatori (Groat \& Wang, 2013) untuk mendapatkan nilai kenyamanan termal pengguna ruang terhadap kondisi iklim mikro di lingkungan gedung dekanat. Hasil data 
kuesioner ini kemudian dibandingkan dengan nilai Temperature Humidity Index (THI) yang sudah diperoleh nantinya. Penyebaran kuesioner dilakukan selama 2 (dua) minggu pada bulan Agustus 2020 dengan jumlah responden FEB 30 orang dan 30 orang responden dari $\mathrm{FH}$ dengan usia rata-rata responden pria adalah 19.8 tahun, dan responden wanita 19.75 tahun. Responden diminta untuk mengevaluasi kenyamanan suhu udara di ruang transisi (threshold).

\section{HASIL DAN PEMBAHASAN}

Berdasarkan data iklim makro pada bulan Agustus 2020 di kota Bengkulu memiliki suhu udara dengan nilai rata-rata pagi $24.59^{\circ} \mathrm{C}$, siang hari $34.16^{\circ} \mathrm{C}$, dan sore hari $30.05^{\circ} \mathrm{C}$. untuk nilai kelembaban pada pagi hari $94 \%$, siang hari $70 \%$, dan sore hari $71 \%$. Melihat data di atas disimpulkan bahwa dalam skala kota Bengkulu memenuhi syarat selang kenyamanan pada nilai kelembaban dan suhu udara pagi hari (Meteoblue, 2020).
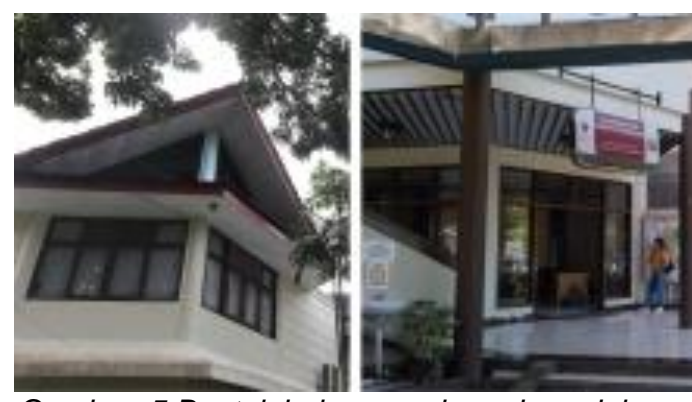

Gambar 5 Bentuk bukaan pada gedung dekanat FEB

Bentuk arsitektural gedung dekanat FEB tersusun atas ruang hexagonal dengan bentuk atap pelana pada tutupannya. Bangunan ini memiliki 1 (satu) ruang transisi (threshold) di depan pintu utama. Bangunan ini didominasi oleh bukaan jendela pada tiap sisi bangunan, sehingga sirkulasi udara dan pencahayaan matahari masuk leluasa ke dalam gedung FEB. Kawasan FEB didominasi oleh vegetasi hijau dan tutupan rumput yang dominan.
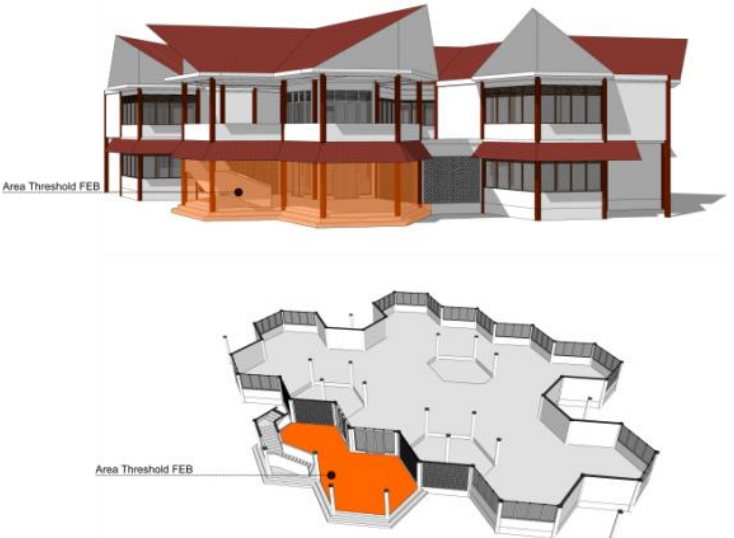

Gambar 6 Area threshold di Fakultas Ekonomi dan Bisnis (FEB)

Dari hasil data pengukuran yang didapat yaitu pada gedung FEB memiliki nilai suhu yang tidak jauh berbeda antara ruang dalam dan ruang transisi. Pada pagi hari kondisi suhu cenderung nyaman dan kelembaban lebih tinggi, namun pada siang dan sore hari nilai suhu cenderung tinggi.

Tabel 2. Nilai rata-rata hasil pengukuran di Fakultas Ekonomi dan Bisnis (FEB)

\begin{tabular}{|c|c|c|c|c|c|}
\hline Waktu & $\begin{array}{c}\text { Suhu } \\
\text { Luar } \\
\left({ }^{\circ} \mathrm{C}\right)\end{array}$ & $\begin{array}{c}\text { Suhu } \\
\text { Dalam } \\
\left({ }^{\circ} \mathrm{C}\right)\end{array}$ & $\begin{array}{c}\text { Kelemba } \\
\text { ban } \\
\text { Udara } \\
\text { Rg. Luar } \\
(\%)\end{array}$ & $\begin{array}{c}\text { Kelemb } \\
\text { aban } \\
\text { Udara } \\
\text { Rg. } \\
\text { Dalam } \\
(\%)\end{array}$ & THI \\
\hline $\begin{array}{c}\text { Pagi } \\
(06.00- \\
08.00)\end{array}$ & 25.96 & 26.12 & 81.68 & 80.68 & 25.01 \\
\hline $\begin{array}{c}\text { Siang } \\
(11.00- \\
14.00)\end{array}$ & 33.43 & 33.38 & 55.48 & 55.31 & 30.46 \\
\hline $\begin{array}{c}\text { Sore } \\
(16.00- \\
18.00)\end{array}$ & 32.65 & 33.07 & 60.75 & 60.07 & 30.09 \\
\hline $\begin{array}{c}\text { Rata - } \\
\text { rata }\end{array}$ & $\mathbf{3 0 . 6 8}$ & $\mathbf{3 0 . 8 6}$ & $\mathbf{6 5 . 9 7}$ & $\mathbf{6 5 . 3 5}$ & $\mathbf{2 8 . 5 2}$ \\
\hline
\end{tabular}

Berdasarkan nilai suhu udara dan kelembaban pada tabel 1, ditemukan bahwa nilai Temperatur Humidity Index (THI) pada gedung FEB pada pagi hari dengan nilai 25.01, siang hari 30.46, dan sore hari 30.09. Sehingga disimpulkan bahwa pada kondisi pagi hari nilai THI berada di kategori nyaman, dan pada siang dan sore hari memiliki nilai yang relatif nyaman. Hal ini berarti dengan kondisi bentuk atap pada area transisi (threshold) dan kondisi kawasan yang ada mampu memberi pengaruh pada perubahan nilai suhu dan kelembaban.

hasil kondisi termal dengan menggunakan perhitungan Rayman di area threshold dekanat 
FEB dapat dilihat pada tabel 3 untuk responden pria dan tabel 4 untuk responden wanita.

Tabel 3 Hasil responden wanita di Fakultas FEB berdasarkan perhitungan Rayman

\begin{tabular}{|c|c|c|c|c|}
\hline $\begin{array}{c}\text { Waktu } \\
\text { Wawancara }\end{array}$ & Tmrt & PMV & PET & SET \\
\hline 9:45:01 & 18.6 & 0.8 & 23.6 & 21.5 \\
\hline $9: 56: 10$ & 18.6 & -2.8 & 23.6 & 20.3 \\
\hline $10: 11: 11$ & 22.2 & -1.6 & 27.3 & 20.7 \\
\hline $10: 32: 30$ & 22.2 & -1.4 & 27.5 & 22.5 \\
\hline $11: 09: 10$ & 24.7 & -0.7 & 30.4 & 22.8 \\
\hline $11: 36: 03$ & 24.7 & 0.6 & 30.4 & 21.1 \\
\hline $9: 34: 12$ & 17.3 & -3.7 & 22.7 & 19.9 \\
\hline $10: 43: 18$ & 22.1 & -1.2 & 27.1 & 20.7 \\
\hline $11: 03: 45$ & 25 & 0.2 & 31 & 23 \\
\hline $11: 52: 11$ & 25 & 0.5 & 30.9 & 23 \\
\hline $9: 42: 06$ & 16.8 & 0.1 & 22.3 & 21 \\
\hline $10: 21: 34$ & 22.4 & 1.7 & 27.5 & 23.8 \\
\hline $10: 44: 21$ & 22.4 & 1.6 & 27.5 & 24.6 \\
\hline $11: 05: 21$ & 24.6 & 2.3 & 30.4 & 26.4 \\
\hline $11: 57: 19$ & 24.6 & 2.3 & 30.3 & 25.9 \\
\hline $9: 17: 21$ & 15.5 & 0.1 & 20.9 & 21.6 \\
\hline $9: 29: 34$ & 15.5 & 0.2 & 20.9 & 21.6 \\
\hline $10: 34: 41$ & 21.7 & 1.6 & 26.9 & 24.1 \\
\hline $10: 41: 32$ & 21.7 & 1.4 & 26.7 & 24 \\
\hline $11: 21: 34$ & 24.6 & 2.2 & 30.3 & 26.6 \\
\hline $11: 40: 21$ & 24.6 & 2.2 & 30.3 & 26.6 \\
\hline $9: 21: 34$ & 16.1 & -0.1 & 21.6 & 21.1 \\
\hline $10: 34: 25$ & 22.2 & 1.8 & 27.6 & 24.5 \\
\hline $11: 41: 12$ & 24.4 & 2 & 29.9 & 25.7 \\
\hline Rata-rata & 21.56 & 0.42 & 26.98 & 23.04 \\
\hline
\end{tabular}

Tabel 4 Hasil responden pria di Fakultas FEB berdasarkan perhitungan Rayman

\begin{tabular}{|c|c|c|c|c|}
\hline $\begin{array}{c}\text { Waktu } \\
\text { Wawancara }\end{array}$ & Tmrt & PMV & PET & SET \\
\hline $9: 47: 56$ & 17.3 & 0.7 & 22.8 & 21.7 \\
\hline $10: 01: 34$ & 22.1 & 2 & 27.8 & 22.8 \\
\hline $9: 14: 18$ & 16.8 & 0.7 & 22.2 & 20.1 \\
\hline $9: 53: 27$ & 16.1 & 0.7 & 21.4 & 21.9 \\
\hline $10: 47: 34$ & 22.2 & 2.7 & 28.3 & 33.2 \\
\hline 11:23:01 & 24.4 & 2 & 30.1 & 26.1 \\
\hline Rata-rata & $\mathbf{1 9 . 8 2}$ & $\mathbf{1 . 4 7}$ & $\mathbf{2 5 . 4 3}$ & $\mathbf{2 4 . 3 0}$ \\
\hline
\end{tabular}

Berdasarkan nilai skala PET dan tingkat stress fisiologis, dapat diketahui bahwa responden pria merasakan kondisi nyaman dan tidak terdapat stress termal dalam merespon kondisi area threshold, namun responden wanita cenderung mendekati kondisi sedikit hangat dan mengalami stress panas sedang.
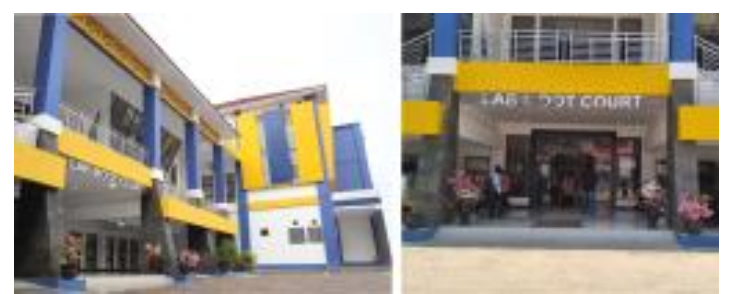

Gambar 7 Bentuk bukaan pada gedung dekanat $\mathrm{FH}$

Bangunan dekanat $\mathrm{FH}$ terdiri dari 2 masa bangunan yang disatukan dengan jalur koridor pada bangunan. Bangunan ini berbentuk persegi dengan jenis bentuk atap perisai pada tutupannya. Pada area transisi bangunan didominasi oleh material lantai keramik dan memiliki minim bukaan dengan lebar teras sejauh 5 (lima) meter. Kawasan FH di depan bangunan didominasi oleh tutupan paving beton dengan penambahan air mancur sebagai ornament lansekap.

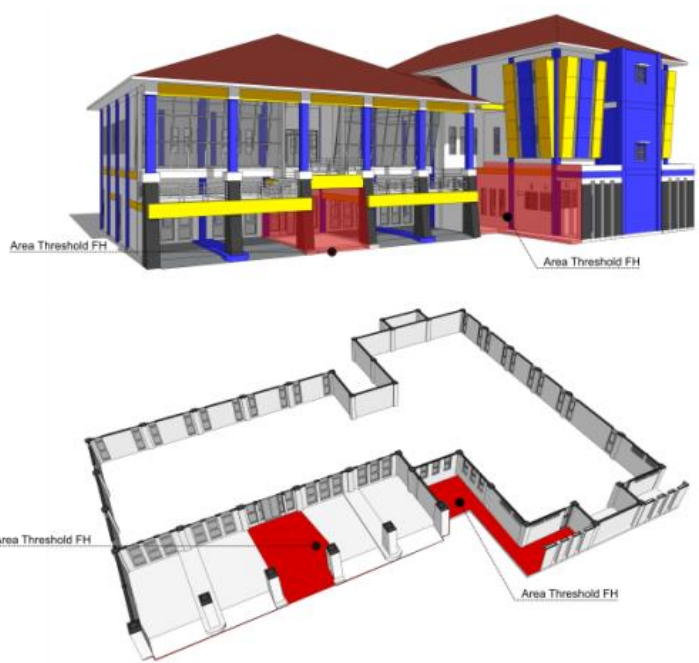

Gambar 8 Area threshold di Fakultas Hukum (FH)

Nilai rata-rata suhu dan kelembaban pada gedung $\mathrm{FH}$ sedikit lebih tinggi kondisinya dengan gedung dekanat FEB. Kondisi suhu dan kelembaban pada pagi, siang, dan sore tidak jauh berbeda dengan gedung FEB. Pada pagi hari cenderung nyaman dan cenderung tinggi pada siang dan sore hari. 
Tabel 5. Nilai rata-rata hasil pengukuran di Fakultas Hukum (FH)

\begin{tabular}{|c|c|c|c|c|c|}
\hline Waktu & $\begin{array}{c}\text { Suhu } \\
\text { Luar } \\
\left({ }^{\circ} \mathrm{C}\right)\end{array}$ & $\begin{array}{c}\text { Suhu } \\
\text { Dalam } \\
\left({ }^{\circ} \mathrm{C}\right)\end{array}$ & $\begin{array}{c}\text { Kelemba } \\
\text { ban } \\
\text { Udara } \\
\mathbf{R g . ~ L u a r} \\
(\%)\end{array}$ & $\begin{array}{c}\text { Kelemb } \\
\text { aban } \\
\text { Udara } \\
\text { Rg. } \\
\text { Dalam } \\
(\%)\end{array}$ & THI \\
\hline $\begin{array}{c}\text { Pagi } \\
(06.00- \\
08.00)\end{array}$ & 26.40 & 26.20 & 79.62 & 81.40 & 25.32 \\
\hline $\begin{array}{c}\text { Siang } \\
(11.00- \\
14.00)\end{array}$ & 33.96 & 33.88 & 54.58 & 53.23 & 30.87 \\
\hline $\begin{array}{c}\text { Sore } \\
(16.00- \\
18.00)\end{array}$ & 33.33 & 33.23 & 61.03 & 60.51 & 30.74 \\
\hline $\begin{array}{c}\text { Rata - } \\
\text { rata }\end{array}$ & 31.23 & $\mathbf{3 1 . 1 0}$ & $\mathbf{6 5 . 0 8}$ & $\mathbf{6 5 . 0 5}$ & $\mathbf{2 8 . 9 7}$ \\
\hline
\end{tabular}

Nilai Temperatur Humidity Index (THI) pada gedung $\mathrm{FH}$ dikategorikan nyaman dengan kondisi pada pagi hari dengan nilai 25.32. THI pada siang hari 30.87 dan sore hari 30.74 sehingga masuk kategori relatif nyaman. Kondisi lingkungan luar dan lebar teras pada gedung $\mathrm{FH}$ mempengaruhi nilai $\mathrm{THI}$, yang cenderung tinggi disbanding dengan gedung FEB.

Tabel 6 Hasil responden wanita di Fakultas FH berdasarkan perhitungan Rayman

\begin{tabular}{|c|c|c|c|c|}
\hline $\begin{array}{c}\text { Waktu } \\
\text { Wawancara }\end{array}$ & Tmrt & PMV & PET & SET \\
\hline $9: 14: 18$ & 18.7 & 0.6 & 23.7 & 23.1 \\
\hline $9: 42: 06$ & 18.7 & 0.1 & 23.6 & 22.4 \\
\hline $10: 01: 34$ & 22.2 & 1.6 & 27.4 & 23.8 \\
\hline $10: 43: 18$ & 22.2 & 1.6 & 27.4 & 23.9 \\
\hline $11: 03: 45$ & 23.3 & 1.8 & 28.7 & 25.6 \\
\hline $11: 52: 11$ & 23.3 & 1.8 & 28.7 & 25.1 \\
\hline $9: 45: 01$ & 17.9 & 0.6 & 23.1 & 22.9 \\
\hline $10: 32: 30$ & 22.1 & 1.6 & 27.3 & 20.7 \\
\hline 11:09:10 & 25.7 & -0.2 & 30.1 & 23.1 \\
\hline $11: 36: 03$ & 25.7 & 2.3 & 30.2 & 27.3 \\
\hline $9: 21: 34$ & 17.1 & 0.2 & 22.6 & 21.8 \\
\hline $10: 21: 34$ & 22.4 & 1.8 & 27.8 & 24.5 \\
\hline $11: 57: 19$ & 24.7 & 2.2 & 30.2 & 26.6 \\
\hline $9: 47: 56$ & 16 & 0.3 & 21.4 & 21.9 \\
\hline $10: 34: 25$ & 21.7 & -1.7 & 26.9 & 20.8 \\
\hline $10: 47: 34$ & 21.7 & 1.4 & 26.7 & 24 \\
\hline $11: 23: 01$ & 25.3 & 2.5 & 31.3 & 27.1 \\
\hline $11: 41: 12$ & 25.3 & 2.5 & 31.3 & 27.1 \\
\hline $9: 17: 21$ & 16.9 & 0.4 & 22 & 20.7 \\
\hline $9: 29: 34$ & 16.9 & 0.6 & 22 & 21.4 \\
\hline
\end{tabular}

\begin{tabular}{|c|c|c|c|c|}
$10: 34: 41$ & 21.4 & 1.4 & 26.5 & 23.3 \\
\hline $10: 41: 32$ & 21.4 & 1.4 & 26.7 & 24.8 \\
\hline $11: 21: 34$ & 23.7 & 1.8 & 29.3 & 25.9 \\
\hline $11: 40: 21$ & 23.7 & 2 & 29.3 & 24.9 \\
\hline Rata-rata & $\mathbf{2 1 . 5 8}$ & $\mathbf{1 . 1 9}$ & $\mathbf{2 6 . 8 4}$ & $\mathbf{2 3 . 8 6}$ \\
\hline
\end{tabular}

Tabel 7 Hasil responden pria di Fakultas FH berdasarkan perhitungan Rayman

\begin{tabular}{|c|c|c|c|c|}
\hline $\begin{array}{c}\text { Waktu } \\
\text { Wawancara }\end{array}$ & Tmrt & PMV & PET & SET \\
\hline $9: 56: 10$ & 17.9 & 1 & 23.2 & 22.6 \\
\hline $10: 11: 11$ & 22.1 & 2 & 27.8 & 26.3 \\
\hline $9: 53: 27$ & 17.1 & 0.9 & 22.4 & 22.5 \\
\hline $10: 44: 21$ & 22.4 & 1.8 & 27.8 & 25.4 \\
\hline $11: 05: 21$ & 24.7 & 2.2 & 30.2 & 22.9 \\
\hline $9: 34: 12$ & 16 & 0.7 & 21.4 & 21.5 \\
\hline Rata-rata & $\mathbf{2 0 . 0 3}$ & $\mathbf{1 . 4 3}$ & $\mathbf{2 5 . 4 7}$ & $\mathbf{2 3 . 5 3}$ \\
\hline
\end{tabular}

Nilai skala PET dan tingkat stress fisiologis, di area threshold dekanat $\mathrm{FH}$ diketahui bahwa responden pria merasakan kondisi nyaman dan tidak terdapat stress termal dalam merespon kondisi area threshold, namun kondisi tingkat stress fisoilogis responden wanita cenderung mendekati kondisi sedikit hangat dan mengalami stress panas sedang.

Dari hasil penyebaran kuesioner di gedung dekanat FEB dan FH didapatkan, mayoritas responden merasa nyaman dengan kondisi suhu ruang transisi dengan persentase responden sebanyak $56 \%$ di FEB dan $56 \%$ di $\mathrm{FH}$. 
= Sangat Tidak Nyaman $\quad$ Kurang Nyaman $\quad$ Nyaman $\quad$ Sangat Nyaman

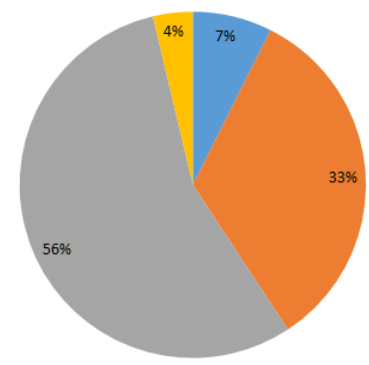

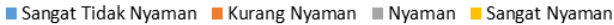

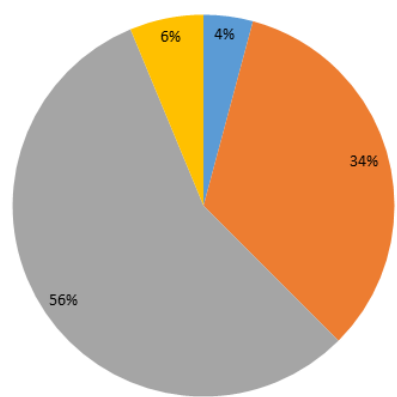

Gambar 9 Hasil responden gedung dekanat FEB (atas), dan gedung dekanat FH (bawah)

Berdasarkan hasil respondensi kuesioner terhadap hasil analisis kenyamanan THI dan perhitungan Rayman, disimpulkan bahwa responden pria dan wanita merasakan nyaman dengan kondisi area threshold.

\section{KESIMPULAN}

Gedung Fakultas Ekonomi dan bisnis (FEB) dan Fakultas Hukum (FH) memiliki kondisi bangunan yang berbeda ditinjau dari usia bangunan, bentuk bangunan, dan arah bangunan terhadap orientasi matahari. Kondisi suhu udara dan kelembaban di kedua bangunan ini dipengaruhi oleh kondisi bentuk bangunan dan lingkungan sekitar. Kondisi ternyaman pada bangunan didapat pada waktu pagi hari dengan suhu udara rata-rata $26{ }^{\circ} \mathrm{C}$ dan nilai kelembaban $80 \%$. Hasil kuesioner menyimpulkan pengguna merasa nyaman dan sesuai dengan nilai Temperatur Humidity Index (THI).

\section{UCAPAN TERIMA KASIH}

Ucapan terima kasih peneliti sampaikan kepada Universitas Bengkulu sebagai selaku pemberi bantuan dana penelitian pembinaan Universitas yang bersumber dana DIPA tahun 2020 dengan nomor kontrak 2052/UN30.15/PG/2020.

\section{DAFTAR PUSTAKA}

Badan Standardisasi Nasional. (2001). Tata cara perancangan sistem pencahayaan buatan pada bangunan gedung. SNI 036575-2001, pp. 1-32.

Dikwatama, F. ... Mensana, A. (2019). Peningkatan Interaksi Publik Melalui Penerapan Threshold Space Pada Area Komersial Di Kawasan Mangga Besar, Jakarta. SMART \#4 - Seminar on Architecture Research \& Technology, 67-88. Yogyakarta, Indonesia: Universitas Kristen Duta Wacana.

Effendy, S. (2007). Keterkaitan Ruang Terbuka Hijau dengan Urban Heat Island Wilayah Jabodetabek. Institut Pertanian Bogor, Bogor.

GreenMetric, U. (2019). List of Universities in Each Region (2018) Rangking by Region - Asia.

Groat, L. N., \& Wang, D. (2013). Architectural Research Methods. Ner Jersey: John Wiley \& Sons, Inc.

Höppe, P. (1999). The Physiological Equivalent Temperature - A Universal Index for The Biometeorological Assessment of The Thermal Environment. Int J Biometeorol, 43 : 7175.

Matzarakis, A., \& Rutz, F. (2006). RayMan: A TOOL FOR RESEARCH AND EDUCATION IN APPLIED CLIMATOLOGY. 8th CONFERENCE ON METEOROLOGY-CLIMATOLOGYATMOSPHERIC PHYSICS, 161-168. Athens, Greek.

MENKES:NO.261/MENKES/SK/II/1998. (1998). Persyaratan Kesehatan Lingkungan Kerja. Jakarta, Indonesia.

Meteoblue. (2020). Iklim Kota Bengkulu.

Nieuwolt, S. (1977). Tropical Climatology. London: Wiley.

Nio, S., \& Dewi, J. (2017). Threshold Space sebagai Pendekatan Desain Ruang Terbuka di Kawasan Kota Tua Jakarta. Seminar HEritage Ikatan Peneliti Lingkungan Binaan Indonesia (IPLBI), B255-B260.

https://doi.org/10.32315/sem.1.b255

Paramita, B., \& Matzarakis, A. (2019). Urban morphology aspects on microclimate in a hot and humid climate. Geographica Pannonica, 23(4), 398-410. https://doi.org/10.5937/gp23-24260

Sanger, Y. Y. J. ... Rombang, J. A. (2016). Pengaruh Tipe Tutupan Lahan Terhadap Iklim Mikro Di Kota Bitung. AgriSosioekonomi, 12(3A), 105-116. https://doi.org/10.35791/agrsosek.12.3a.2 
016.14355

Santi ... Aspin. (2019). Identifikasi Iklim Mikro dan Kenyaman Termal Ruang Terbuka Hijau di Kendari. NALARs Jurnal Arsitektur, 18(1), 23-34.

Sumaryata, M. A. ... Koerniawan, M. D. (2019). Kenyamanan Termal Pada Koridor Kampus Institut Teknologi Bandung Dengan Analisis Rayman. Jurnal Lingkungan Binaan Indonesia, 8(2), 95-102. https://doi.org/10.32315/jlbi.8.2.95

Talarosha, B. (2005). Menciptakan Kenyamanan Thermal Dalam Bangunan. Jurnal SIstem Teknik Industri, 6(3), 148158. 